\title{
Morphology of the lingual papillae of the Asian short-clawed otter
}

\author{
By \\ Shoichi EMURA ${ }^{1}$ and Kazue SUGIYAMA ${ }^{2}$ \\ ${ }^{1}$ Heisei College of Health Sciences, Gifu 501-1131, Japan \\ ${ }^{2}$ United Graduate School of Drug Discovery and Medical Information Sciences, Gifu 501-1193, Japan \\ -Received for Publication, September 2, 2016-
}

Key Words: Asian short-clawed otter, lingual papillae, scanning electron microscopy

\begin{abstract}
Summary: We examined the dorsal lingual surface of an adult Asian short-clawed otter (Aonyx cinerea) by using scanning electron microscopy. The filiform papilla on the lingual apex had some pointed processes. The connective tissue core of the filiform papillae consisted of several rod-like processes, and the connective tissue core with a long process was rarely observed. The filiform papilla on the lingual body had several pointed processes and the fungiform papilla had smooth surface. The connective tissue core of the filiform papillae consisted of a large main and several small processes. The vallate papillae were surrounded by a groove and some pads, and many processes were observed on this surface. The tongue of the Asian short-clawed otter was different from that of the Japanese marten belong to family Mustelidae.
\end{abstract}

Many studies report the structures of the lingual surfaces of various animals. Some scanning electron microscopy (SEM) studies have been performed on the tongues of animals in the order Carnivora, including the cat (Boshell et al., 1982), dog (Iwasaki and Sakata, 1985), mongoose (Iwasaki et al., 1987), Japanese weasel (Furubayashi et al., 1989), sea otter (Shimoda et al., 1996), bush dog (Emura et al., 2000), panther and Asian black bear (Emura et al., 2001), lion (Emura et al., 2003), tiger (Emura et al., 2004), Japanese marten (Emura et al., 2007 ), jaguar (Emura et al., 2013), fishing cat (Emura et al., 2014a) and black-backed jackal (Emura and Sugiyama, 2014b). These studies have revealed variations in the morphology and distribution of papillae on the dorsal lingual surface among animal species.

However, no SEM study of the tongue of the Asian short-clawed otter (Aonyx cinerea) has been performed. Therefore, this study examined the dorsal lingual surface of the Asian short-clawed otter and compared the features with those of other mammals.

\section{Materials and Methods}

The tongue of one Asian short-clawed otter (Aonyx cinerea) of the family Mustelidae was used in this study.
The tongue was fixed in $10 \%$ formalin. Small blocks containing papillae were cut with a razor blade and post-fixed with $1 \%$ osmium tetroxide for $1 \mathrm{~h}$. The specimens were subsequently dehydrated through a graded series of acetone and critical-point-dried. To show the three-dimensional connective tissue structure of the lamina propria of the mucosa, some of the samples were washed in distilled water after fixation and macerated in $3.5 \mathrm{~N} \mathrm{HCl}$ at $35{ }^{\circ} \mathrm{C}$ for 2 days. After maceration, the tissues were washed in distilled water, post-fixed in $1 \%$ osmium tetroxide for $1 \mathrm{~h}$, and dehydrated in a series of acetone and critical-point-dried. All specimens were sputtered with Pt-Pd before being examined by SEM (Hitachi S-3500N, Tokyo, Japan) at an acceleration voltage of 10 $\mathrm{kV}$.

\section{Results}

Macroscopically, the tongue of the Asian short-clawed otter was approximately $5 \mathrm{~cm}$ long. Filiform papillae were distributed over the entire dorsal surface of the lingual body (Fig. 1). Vallate papillae were located on both sides of the posterior end of the lingual body (Fig. 1). There were no foliate papillae.

SEM showed that the filiform papilla on the lingual 


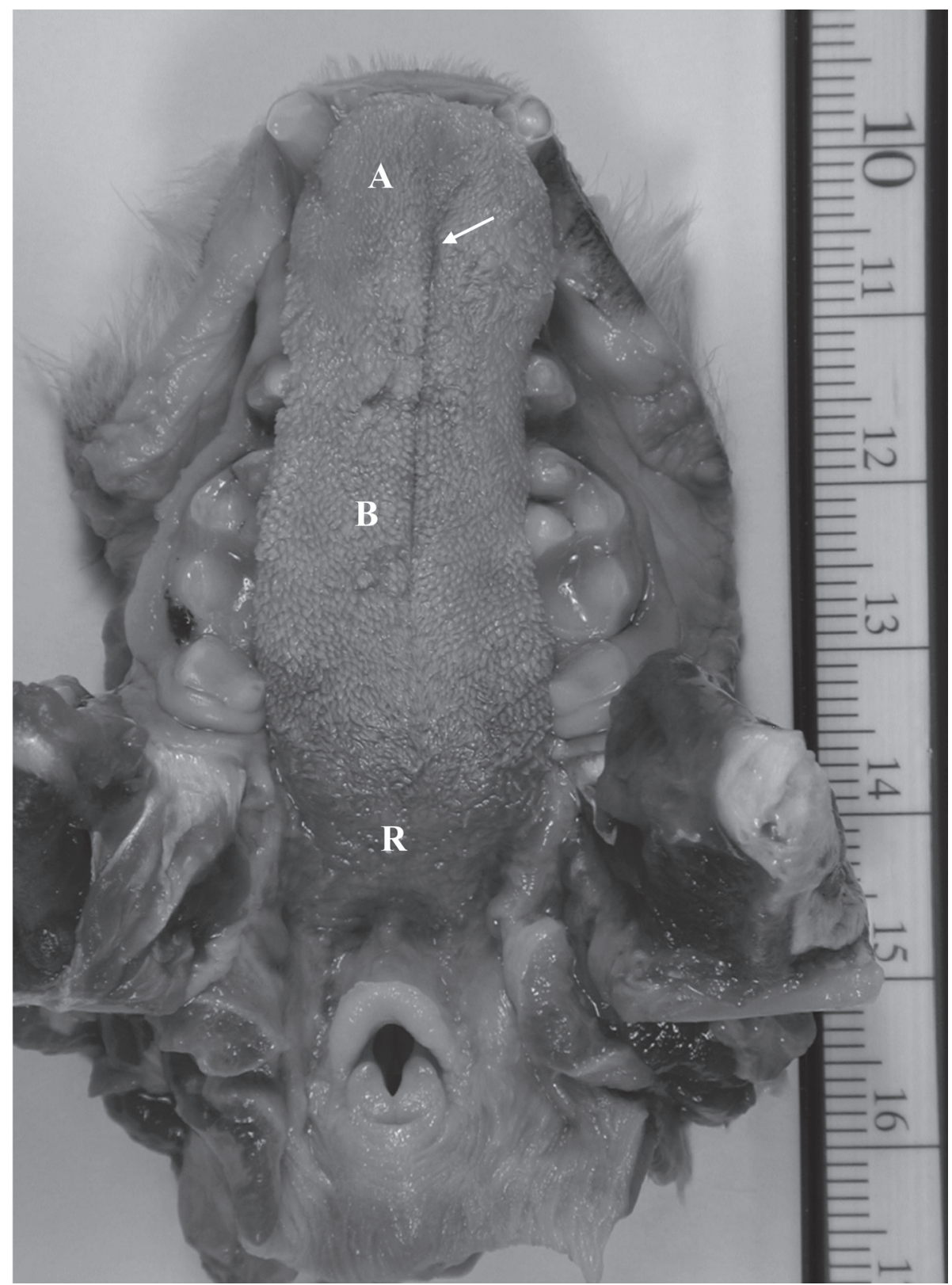

Fig. 1. Macrograph of an Asian short-clawed otter tongue. $A=$ lingual apex. $B=$ lingual body. $\mathrm{R}=$ lingual root. Arrow $=$ median groove.

apex had some pointed processes (Fig. 2a). The connective tissue core of the filiform papillae consisted of several rod-like processes, and the connective tissue core with a long process was rarely observed (Fig. 2b). The filiform papilla on the lingual body had several pointed processes and the fungiform papilla had smooth surface (Fig. 3a). The connective tissue core of the filiform papillae consisted of a large main and several small processes (Fig. 3b). The vallate papillae were surrounded by a groove and some pads, and many processes were observed on this surface (Fig. 4).

\section{Discussion}

In the cat (Boshell et al., 1982), lion (Emura et al., 2003), tiger (Emura et al., 2004), jaguar (Emura et al., 2013) and fishing cat (Emura et al, 2014a), the filiform papillae on the anterior part of the lingual body were large and cylindrical; this is a characteristic of the filiform papillae in the family Felidae.

Meanwhile, in the beagle dog (Iwasaki and Sakata 1985), bush dog (Emura et al, 2000), silver fox (Jackowiak and Godynicki 2004), raccoon dog and fox (Emura 

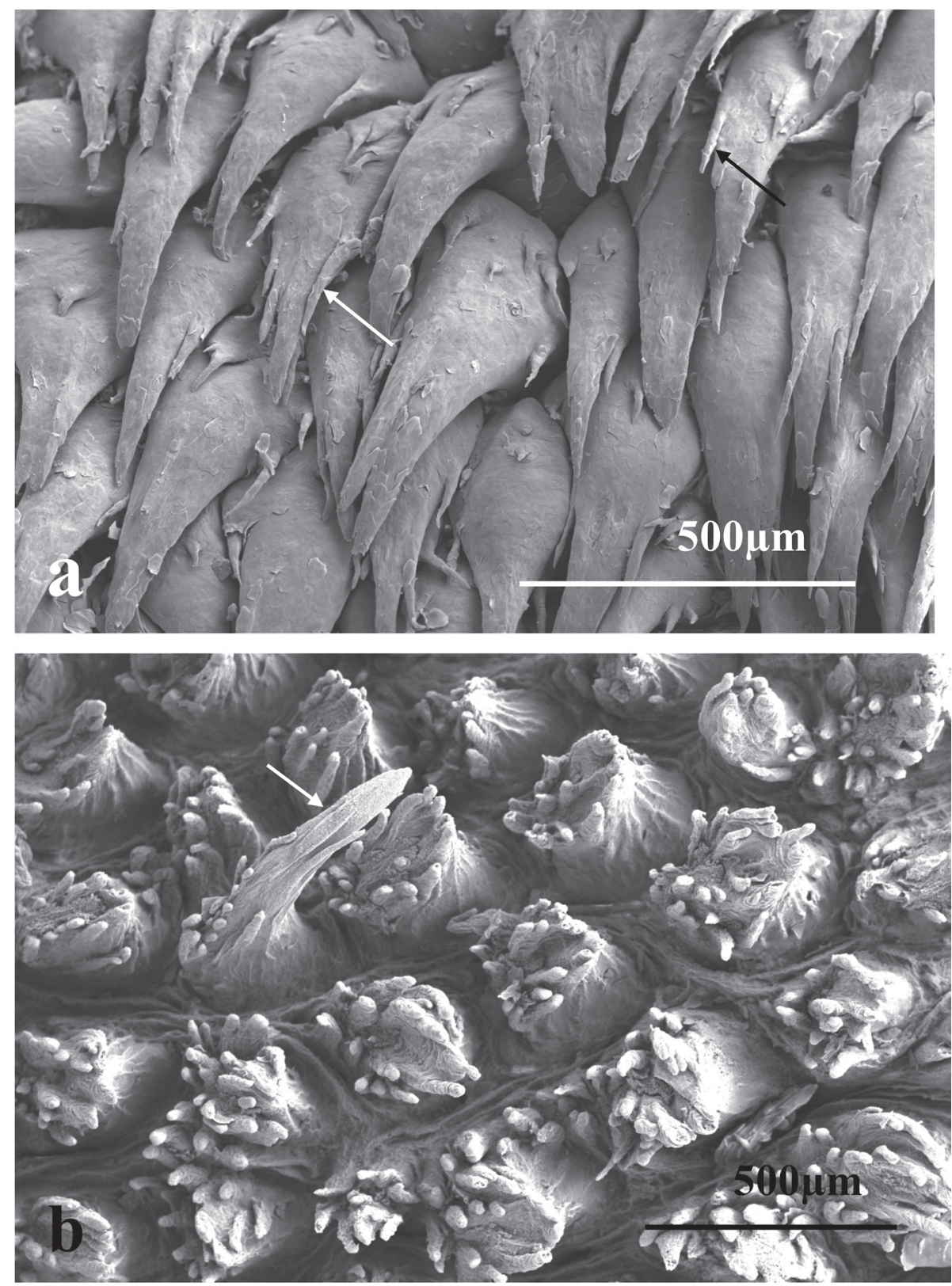

Fig. 2. (a, b) SEM micrographs of the lingual apex. The filiform papilla on the lingual apex has some pointed processes (arrows). The connective tissue core of the filiform papilla consists of several rod-like processes and the connective tissue core with a long process (arrow) is observed.

et al, 2006) and black-backed jackal (Emura et al, 2014b) of the family Canidae, the filiform papillae which exhibited large and cylindrical shape were not observed on lingual body.

In the Japanese weasel (Furubayashi et al., 1989), four types of papillae were present on the mucous membrane of the tongue; filiform, fungiform, vallate and foliate papillae.

In the Japanese marten (Emura et al, 2007) of the family Mustelidae, a small filiform papilla on the apical surface of the tongue had several pointed processes. The connective tissue core of the small filiform papilla consisted of several small processes. A large filiform papilla on the lingual body consisted of a main and some secondary papillae. The connective tissue core of the large filiform papilla consisted of processes of various sizes. The fungiform papilla was round in shape. The vallate papilla was located on both sides of the posterior end of the lingual body and the papilla was surrounded by groove and crescent pad. The foliate papilla was seen on 

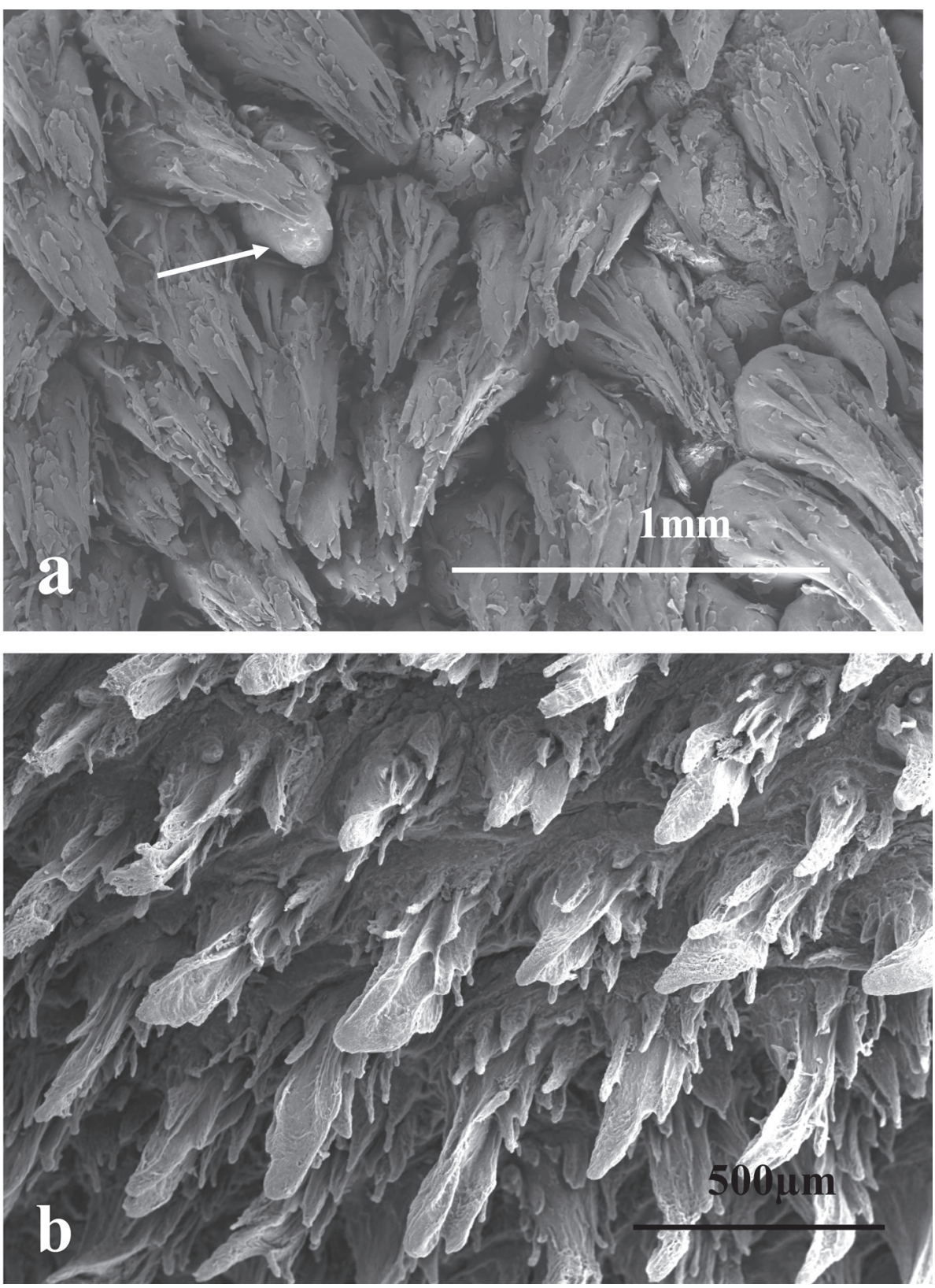

Fig. 3. (a, b) SEM micrographs of the lingual body. The filiform papilla on the lingual body has several pointed processes and the fungiform papilla (arrow) is smooth surface. The connective tissue core of the filiform papilla consists of a large main process and several small processes.

the dorsolateral aspect on the tongue and some ridges and grooves were exposed reciprocally.

In the ferret and Siberian weasel (Emura, 2008), a filiform papilla on the apical surface of the tongue had several pointed processes. The connective tissue core of the filiform papilla consisted of several small processes. A filiform papilla of the lingual body consisted of a main and one or two secondary papillae. The connective tissue core of the filiform papilla consisted of processes of various sizes. The fungiform papillae are round in shape. The vallate papilla was located on both sides of the posterior end of the lingual body and each papilla was surrounded by groove. The foliate papillae were not observed.

In this study, the filiform papilla on the lingual apex had some pointed processes. The connective tissue core of the filiform papillae consisted of several rod-like processes, and the connective tissue core with a long process was rarely observed. The filiform papilla on the lingual body had several pointed processes and the 


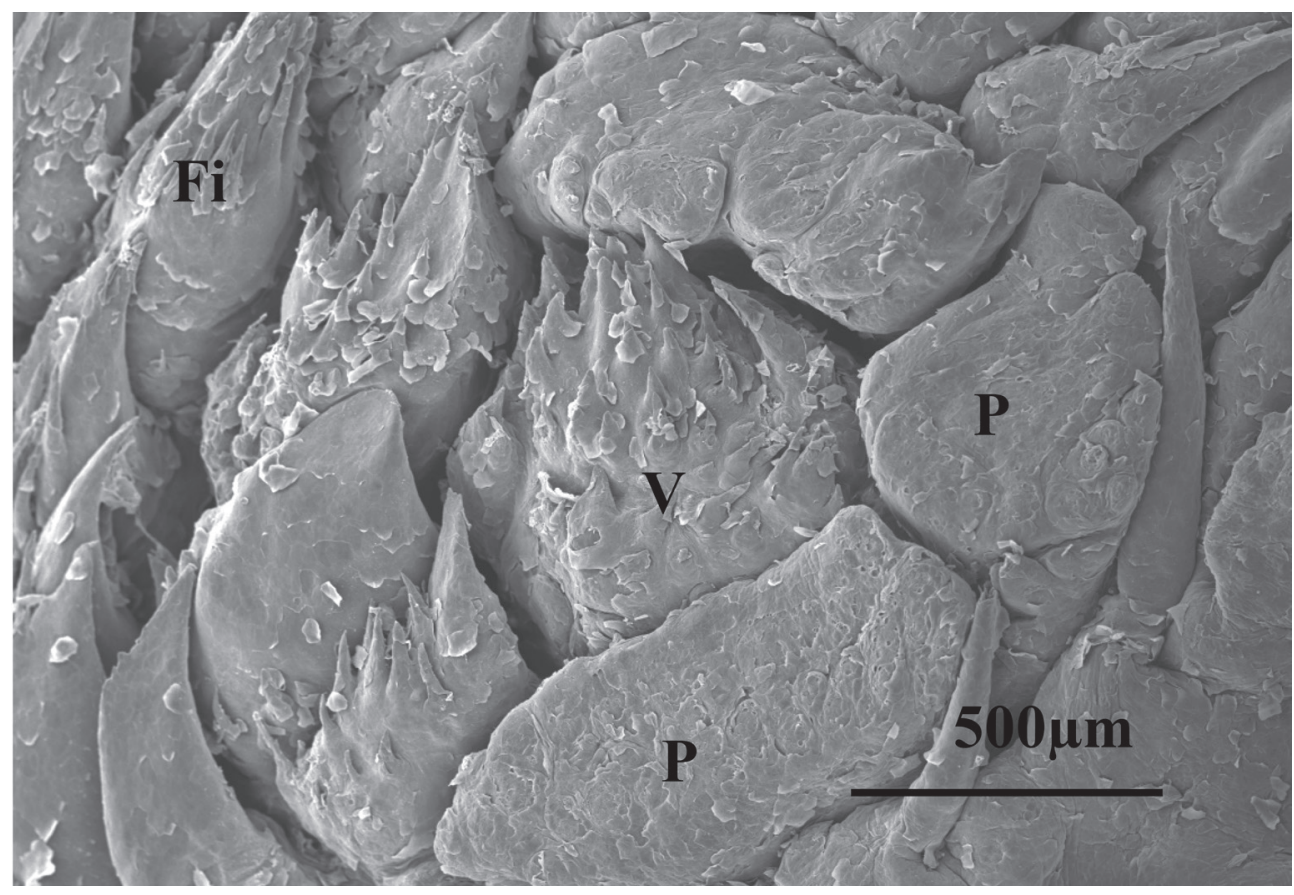

Fig. 4. SEM micrographs of the vallate papilla. The vallate papilla (V) is surrounded by a groove and some pads (P), and many processes are showed on surface of the vallate papilla.

fungiform papilla had smooth surface. The connective tissue core of the filiform papillae consisted of a large main and several small processes. The vallate papillae were surrounded by a groove and some pads, and many processes were observed on this surface.

In conclusion, the morphological characteristic of the lingual surface of the Asian short-clawed otter has not large papillae and the foliate papilla on the lingual body. Thus, the tongue of the Asian short-clawed otter is different from that of the family Felidae, and also different from that of the Japanese marten and weasel belong to family Mustelidae.

\section{Acknowledgements}

We are grateful to the staff of Wakayama adventure world for supplying the specimen.

\section{References}

1) Boshell, J.L, Wilborn W.H and Singh B.B. Filiform papillae of cat tongue. Acta Anat 1982; 114:97-105.

2) Emura S. SEM studies on the lingual papillae and their connective tissue cores of the ferret and Siberian weasel (in Japanese). Med Biol 2008; 152:48-56.

3) Emura S, Hayakawa D, Chen H and Shoumura S. Morphology of the dorsal lingual papillae in the newborn panther and Asian black bear. Okajimas Folia Anat Jpn 2001; 78:173-178.

4) Emura S, Hayakawa D, Chen H and Shoumura S. SEM and gross study on the lingual surface of the lion, Panthera leo (in Japanese). Mammalian Science 2003; 43:45-50.

5) Emura S, Hayakawa D, Chen H and Shoumura S. Morphology of the lingual papillae in the tiger. Okajimas Folia Anat Jpn 2004; 81:39-44.

6) Emura $\mathrm{S}$, Okumura $\mathrm{T}$ and Chen $\mathrm{H}$. Morphology of the lingual papillae in the Japanese marten. Okajimas Folia Anat Jpn 2007; 84:77-82.

7) Emura $S$, Okumura $T$ and Chen $H$. Morphology of the lingual papillae in the jaguar. Okajimas Folia Anat Jpn 2013; 89:93-97.

8) Emura $S$, Okumura $T$ and Chen $H$. Morphology of the lingual papillae in the fishing cat. Okajimas Folia Anat Jpn 2014a; 90:7983.

9) Emura S, Okumura T, Chen H and Shoumura S. Morphology of the lingual papillae in the raccoon dog and fox. Okajimas Folia Anat Jpn 2006; 83:73-76.

10) Emura $S$ and Sugiyama K. Morphology of the lingual papillae of the black-backed jackal (Canis mesomelas). Okajimas Folia Anat Jpn 2014b; 91:19-24.

11) Emura S, Tamada A, Hayakawa D, Chen H, Jamali M, Taguchi H and Shoumura S. SEM study on the dorsal lingual surface of the flying squirrel, Petaurista leucogenys. Ann Anat 1999; 181:495498.

12) Emura S, Tamada A, Hayakawa D, Chen $H$ and Shoumura $S$. Morphology of the dorsal lingual papillae in the bush dog (Speothos venaticus). Okajimas Folia Anat Jpn 2000; 77:137-142.

13) Furubayashi R, Sato $E$ and Ishibashi T. Histological pattern of the tongue in the Japanese weasels, Mustera itatsi, with special reference to the morphology and distribution of papillae, taste buds and lingual glands (in Japanese). Acta Anat Nippon 1989; 64:210-214.

14) Iwasaki S, Miyata K and Kobayashi K. Comparative studies of the 
dorsal surface of the tongue in three mammalian species by scanning electron microscopy. Acta Anat 1987; 128:140-146.

15) Iwasaki $S$ and Sakata K. Scanning electron microscopy of the lingual dorsal surface of the beagle dog. Okajimas Folia Anat Jpn 1985; 62:1-14.

16) Jackowiak H and Godynicki S. The scanning electron microscopy of the papillae in the silver fox (Vulpes vulpes fulva, Desmarest, 1820). 2004; 186:179-183.

17) Shimoda $T$, Nakanishi E, Yoshino $S$ and Kobayashi S. Light and scanning electron microscopic study on the lingual papillae in the newborn sea otter Enhydra lutris. Okajimas Folia Anat Jpn 1996; 73:65-74. 